\title{
脳卒中患者の車椅子安全操作管理能力の評価と 歩行能力予後の関連性
}

\author{
——机上の認知機能評価との比較— \\ Relationship between the Assessment of Abilities in Wheelchair Safety Operation \\ Management and Prognosis of Walking Ability in Stroke Patients: \\ A Comparison with the Academic Cognitive Function Test
}

月成 亮輔 ${ }^{1,2)}$ 長井 亮祐 $^{1)}$ 菊池 俊明 ${ }^{1)}$ 宮前 篤 ${ }^{1)}$
宮崎 晶子

RYosuke TSUKINARI, RPT, MA ${ }^{1,2)}$, RYosUKe NAGAI, RPT ${ }^{1)}$, TOSHIAKI KIKUCHI, RPT ${ }^{1)}$, ATSUSHI MIYAMAE, RPT ${ }^{1)}$, MASAKo MIYAZAKI, CP, MA ${ }^{1)}$, SYUICHI ITO, RPT, MSc ${ }^{1)}$, YUMi IKEDA, RPT, PhD ${ }^{3)}$

${ }^{1)}$ Department of Rehabilitation, Ichikawa-shi Rehabilitation Hospital: 4-229-4 Kashiwai-cho, Ichikawa-shi, Chiba 272-0802, Japan TEL+8147-320-7111 E-mail: color-code-waltz@hotmail.co.jp

${ }^{2)}$ Course of Philosophy, Graduate School of Letters, Toyo University

${ }^{3)}$ Department of Physical Therapy, Faculty of Human Health Sciences, Tokyo Metropolitan University

Rigakuryoho Kagaku 33(1): 45-48, 2018. Submitted Jul. 24, 2017. Accepted Aug. 30, 2017.

\begin{abstract}
Purpose] We compared abilities in wheelchair safety operation management (WCSOM) with the academic cognitive function test to examine its usefulness as a prediction factor of walking ability prognosis for stroke patients' walking abilities. [Subjects and Methods] The subjects were 16 initial stroke patients. A clinical psychologist evaluated the academic cognitive function test, and a physical therapist evaluated the WCSOM at hospitalization and one month after hospitalization. Sensitivity, specificity, positive and negative predictive values, and positive and negative likelihood ratios were calculated using the ROC curve's cutoff value for the relationship between each evaluation result and the walking independence level at discharge. [Results] For all items, the WCSOM evaluation was high at accurately predicting the walking independence level at discharge. [Conclusion] The results suggest that evaluation of WCSOM can predict the walking independence level at discharge even in comparison with the academic cognitive function test.
\end{abstract}

Key words: stroke, gait, prognostic prediction

要旨：〔目的〕車椅子安全操作管理能力の評価に関して, 机上の認知機能検査との比較検討を行い, 回復期脳卒中患 者における歩行能力予後予測因子としての有用性を検証することを目的とした。〔対象と方法〕初発脳卒中患者 16 名 を対象とした，入院時 · 入院後 1 カ月時にて, 車椅子安全操作管理能力の評価は担当理学療法士, 机上の認知機能検 査は臨床心理士が評価した。それぞれの評価結果と退院時歩行自立度の関係を ROC 曲線からカットオフ值を算出し, 感度, 特異度, 陽性（陰性）的中率, および陽性（陰性）尤度比を算出した。〔結果〕退院時歩行自立レベルの予測 精度は, 車椅子安全操作管理能力の評価が最も高い結果となった.〔結語〕車椅子安全操作管理能力の評価は, 机上 の認知機能検査との比較においても, 退院時の歩行自立度を高い精度で予測できる可能性があることが示唆された。

キーワード : 脳卒中, 歩行, 予後予測

1) 市川市リハビリテーション病院リハビリテーション部：千葉県市川市柏井町 4-229-4 ( T 272-0802) TEL 047-320-7111

2) 東洋大学大学院 文学研究科 哲学専攻

3) 首都大学東京大学院 人間健康科学研究科 理学療法科学域

受付日 2017 年 7 月 24 日 受理日 2017 年 8 月 30 日 


\section{I.はじめに}

脳卒中患者に扔ける予後予測の研究は，急性期での報 告と比較し，回復期での報告は少ないことが指摘されて いる ${ }^{1)}$ ，回復期脳卒中患者の予後予測研究に打いて，予 測するアウトカムとして退院時の Functional Independence Measure（以下，FIM）を中心とする日常 生活活動 Activities of Daily Living (以下, ADL) ${ }^{1-5}$ ), あ るいは転帰先とする報告が多く ${ }^{6}$, 歩行能力予後に焦点 を当てた報告は，橈ら7) や平野ら 8) の報告に留まって いる。 また，予測因子に着目すると，年齢，身体機能， および移動能力を指標としており，認知機能評価に焦点 を当てた報告はほとんどない，脳卒中後遺症後の認知機 能評価として用いられているものには, Mini-Mental State Examination（以下, MMSE）や改訂長谷川式簡易 知能評価スケール（以下, HDS-R）等の全般的知的機 能スクリーニング検査や, Trail Making Test（以下, $\mathrm{TMT}$ ）等の注意機能評価がある。これらの机上での認 知機能検查は, 急性期においては歩行能力予後との関連 性も報告されている ${ }^{9-12)}$.

リハビリテーション場面に扔いて，患者の ADLの自 立度を高めることができない原因が身体能力であること が明確な場合には，その解決の糸口を見つけやすい。し かし, 脳卒中患者では, 身体能力は十分に有しているに もかかわらず，安全管理や安全配慮が不十分であるため に自立度を高められない症例も多い。その典型例として, 車椅子のブレーキ・フットレスト（以下， $\mathrm{B} / \mathrm{F}$ ) 操作管 理がある。車椅子の $\mathrm{B} / \mathrm{F}$ 操作は, 病院内では主に車椅 子とベッド間，または車椅子とトイレ便座間の移乗動作 の際に，車椅子が動かないように固定するためのブレー キ操作，および足が躓かないようにフットレストを上げ る操作が必要となる。この一連の操作は, 必要性が生じ たときにのみに行う操作であり， B/F 操作自体が行える という「動作遂行能力」とともに，必要なときに $\mathrm{B} / \mathrm{F}$ 操作を実施できるという「管理能力」が必要となる。脳 卒中患者は, $\mathrm{B} / \mathrm{F}$ 操作の動作自体は遂行可能な身体能力 を有しているにもかかわらず， $\mathrm{B} / \mathrm{F}$ 操作が徹底できない ことが多くあり，セラピストや看護師からの声掛けがそ の都度行われてもその状況は改善せずに数力月間続き, 退院時でも車椅子 $\mathrm{B} / \mathrm{F}$ 操作が徹底して行えず自立でき ない患者も稀ではない.

そこで, 我々は先行研究に打いて, 車椅子 $\mathrm{B} / \mathrm{F}$ 操作 管理能力に着目し, 当院（回復期リハビリテーション病 院）入院後 1 力月の時点で, 車椅子の $\mathrm{B} / \mathrm{F}$ 操作管理が 定着していたか否かが，当院退院時の歩行自立レベルに 著明に関係していることを明らかにし，B/F 操作管理の 評価を退院時歩行自立度の予後予測因子として用いる有 用性を報告した ${ }^{13)}$

本研究では, 車椅子 $\mathrm{B} / \mathrm{F}$ 操作管理能力は机上の認知
機能検査では把握できない行為レベルでの認知機能を表 すと仮定し，歩行能力の予後予測因子としての有用性に 関してより詳細に検証するために，机上での認知機能評 価である MMSEや TMT との比較検討を行うことを目 的とした。

\section{II. 対象と方法}

1. 対象

2014 年 12 月～ 2016 年 1 月に当院入院の初発脳卒中 患者 58 名を対象とした。除外項目は，脳卒中の既往の ある症例，下肢の整形外科疾患を有している症例，発症 前に何らかの ADL が非自立であった症例，発症前に屋 内歩行非自立レベルであった症例，入院時に歩行が自立 していた症例，説明に際し同意を得られなかった症例， 再発やその他の疾患で転院した症例, 必要な評価項目の デー夕が必要な時期に得られなかった症例，および車椅 子 B/F 操作が身体的理由で実施できない症例とした。 対象者 58 名のうち，条件を満たす 16 名を対象とした (表 1).

\section{2. 方法}

被験者の背景因子はカルテ記載の情報にて得た。身体 機能評価として, Stroke Impairment Assessment Set Motor（以下, SIAS-M) と Brunnstrom Recovery Stage （以下，BRS）を用い, 担当理学療法士が評価した. MMSE, Trail Making Test PartA (以下, TMT-A)，扔よ び Trail Making Test PartB（以下, TMT-B) は臨床心理 士によって評価が行われた，各評価は，入院時と入院後 1 カ月時点で行った。退院時歩行自立の可否の評価は, 退院時の院内生活での ADL を指標とした。評価の基準 は FIM を参考に病棟歩行 FIM6 以上を自立, FIM5 以下 を非自立とした，評価者は主治医，担当理学療法士，お よび病棟看護師の 3 名にて安全に病棟歩行が行えるかど うかを判断し，最終的には主治医の判断によって自立の 可否が決められた。

車椅子 $\mathrm{B} / \mathrm{F}$ 操作管理能力の評価は, 先行研究 10$)$ と同 様の評価方法にて行った，操作管理は，移乗動作の際に 忘れることなく(1)ブレーキをかける，(2)フットレストの 開閉をする, (3)両足部の位置を肩幅程度に開き足底全面 が床に設置するの 3 つから構成され，また 3 つの項目を 全て行える場合を自立，一つでも行えない場合を非自立 とし, 入院時と入院後 1 力月の時点で, 担当理学療法士 が判断した。なお，今回の研究に際して，車椅子 B/F 操作管理に関して特別な指導・アドバイス・声掛けは 行っていない，患者は入院中の院内の生活において，今 回の研究に関わる外的環境条件は一定であると仮定して 評価を行った。

統計解析では, 入院時㧍よび入院後 1 カ月時点での車 
椅子 $\mathrm{B} / \mathrm{F}$ 操作管理能力, MMSE，および TMT の指標か ら，退院時歩行自立の可否を予測する精度を比較するた めに，それぞれの指標について ROC 曲線から，カット オフ值を算出し, 感度, 特異度, 陽性的中率, 㓌性的中 率，陽性尤度比，および陰性尤度比を算出し，比較検討 を行った。統計解析にはR2.8.1を用いた。

また，退院時における歩行自立群と非自立群について 基本属性の比較を行うために, 年齢と発症から当院入院 までの日数と在院日数を 2 標本 $\mathrm{t}$ 検定にて, MMSE は, Mann-Whitney U 検定にて比較検討した。また同群内で 入院時と入院 1 力月後における MMSE と TMT-A につ いて Wilcoxonの符号付順位和検定を用いて比較した。 有意水準は $5 \%$ とした。

被験者には十分な説明を行い, 研究目的および方法に ついて, 十分に説明し, 同意を得た。また，本研究は市 川市リハビリテーション病院倫理委員会の承諾を受けて 実施した（受付番号 22-3）.

\section{III. 結 果}

退院時歩行自立群は 7 名, 非自立群は 9 名であった。 退院時歩行自立と非自立を分別するMMSEのカットオ フ值は入院時 26 点, 入院後 1 カ月 28 点となり, TMT-A のカットオフ值は入院時 222 秒, 入院後 1 カ月 159 秒となった。 各指標のカットオフ值による, 退院時 歩行自立, 非自立予測の感度, 特異度, 陽性的中率, 陰

表 1 被験者の背景因子

\begin{tabular}{|c|c|}
\hline 年齢（歳） & $66.7 \pm 14.0$ \\
\hline 性別 & 男性 5名：女性 11 名 \\
\hline 身長（cm） & $157.8 \pm 7.7$ \\
\hline 体重（kg） & $57.2 \pm 12.4$ \\
\hline 発症からの当院入院までの期間（日） & $27.8 \pm 13.9$ \\
\hline 入院期間（日） & $148.8 \pm 28.6$ \\
\hline 出血·梗塞 & 脳出血 10 名: 脳梗塞 7 名 \\
\hline 右片麻痺 : 左片麻痺 & 右片麻痺 3 名 : 左片麻痺 14 名 \\
\hline 障害部位 & $\begin{array}{c}\text { 視床 : } 4 \text { 名 被殼 }: 3 \text { 名 放線冠: } 1 \text { 名 } \\
\text { 皮質下: } 1 \text { 名 脳幹部 }: 4 \text { 名 } \\
\text { 内頸動脈 }: 2 \text { 名 中大脑動脈 }: 1 \text { 名 }\end{array}$ \\
\hline BRS 上肢, 手指, 下肢 & $2.9 \pm 1.3, \quad 2.7 \pm 1.5, \quad 3.6 \pm 1.0$ \\
\hline SIAS-M hip, knee, ankle & $2.4 \pm 1.2, \quad 2.3 \pm 1.1, \quad 2.1 \pm 1.3$ \\
\hline 入院時 FIM 合計（運動，認知） & $74.3 \pm 17.7(42.3 \pm 19.4, \quad 29.4 \pm 4.0)$ \\
\hline
\end{tabular}

平均值 \pm 標準偏差.
性的中率, 陽性尤度比, および陰性尤度比を表 2 に示す。 陽性尤度比では入院時車椅子 $\mathrm{B} / \mathrm{F}$ 操作管理能力が最も 高い数值となり, 陰性尤度比では入院後 1 力月 MMSE, 入院後 1 力月車椅子 $\mathrm{B} / \mathrm{F}$ 操作管理能力が最も低い数值 となった。 また, MMSE, TMT-A，および車椅子 B/F 操作管理能力のいずれの評価項目においても, 入院時に 比較し入院後 1 力月時において, 退院時歩行自立レベル の予測精度が高い傾向にあった. TMT-Bに関しては, 複数の患者が課題の理解困難, 遂行困難等の理由から測 定不能となったため, 評価項目として除外した。

また，退院時歩行自立群と非自立群の基本属性のうち， MMSE および TMT-A と車椅子 B/F 操作管理能力の評 価結果を表 3 に示す。院時および入院後 1 力月におけ るMMSEは，退院時歩行自立群の方が非自立群よりも 有意に高得点であった（入院時 $: p=0.01$, 入院後 1 カ 月 : $\mathrm{p}=0.03)$. また退院時歩行非自立群において，入院 時および入院後 1 力月の両時期間で有意差がみられた。 年齢・発症からの当院入院までの期間, 在院日数につい ては, 両群間に有意差は認められなかった。

\section{IV. 考 察}

車椅子 $\mathrm{B} / \mathrm{F}$ 操作管理能力の評価は, 先行研究の報告 と同様に，高い精度で退院時歩行自立レベルを予測でき， その精度は机上検査の MMSEや TMT-A との比較にお いても同程度か, あるいはより優れた指標となる可能性 があることが示唆された. 我々が行った先行研究では, 車椅子 $\mathrm{B} / \mathrm{F}$ 操作管理能力と歩行能力予後との関連を「記 憶」に焦点を当てて考察を進めた ${ }^{13)}$. スクワイヤーの 記憶分類 ${ }^{14)}$ によれば，車椅子 B/F 操作管理に関わる記 憶は身体に関わる非宣言記憶であると考えられるため, 歩行動作の獲得に必要な能力として共通している可能性 があると考察した。認知機能評価として用いられている MMSE は机上検査であり，宣言的記憶に基づくものと 考えられるため, 本研究では, 非宣言記憶に分類される 車椅子 $\mathrm{B} / \mathrm{F}$ 操作管理能力と宣言記憶に分類される MMSEにて, 歩行予後予測精度の観点から比較検討を 行った．結果ではわずかに車椅子 $\mathrm{B} / \mathrm{F}$ 操作管理能力が より精度が高い傾向にあったが，その差は明らかではな

表 2 各評価指標と退院時歩行自立度の関連性

\begin{tabular}{llcccccc}
\hline & & 感度 & 特異度 & 陽性的中率 & 陰性的中率 & 陽性尤度比 & 陰性尤度比 \\
\hline MMSE (入院時) & カットオフ值 26 点 & 0.86 & 0.78 & 0.75 & 0.88 & 3.86 & 0.18 \\
MMSE (入院後 1 カ月) & カットオフ值 28 点 & 1.00 & 0.67 & 0.70 & 1.00 & 3.00 & 0.00 \\
TMT-A (入院時) & カットオフ值 222 秒 & 0.86 & 0.50 & 0.54 & 0.83 & 1.54 & 0.32 \\
TMT-A (入院後1 カ月) & カットオフ值 159 秒 & 0.71 & 0.80 & 0.71 & 0.80 & 3.21 & 0.37 \\
B/F 操作管理 (入院時) & & 0.57 & 0.89 & 0.80 & 0.73 & 5.14 & 0.48 \\
B/F 操作管理 (入院後 1 カ月) & 1.00 & 0.78 & 0.78 & 1.00 & 4.50 & 0.00 \\
\hline
\end{tabular}


表 3 退院時歩行自立群と退院時歩行非自立群の属性比較

\begin{tabular}{lcc}
\hline & \multicolumn{1}{c}{ 入院時 } & 入院後 1 カ月 \\
\hline 退院時歩行自立群 $(7$ 名 $)$ & \\
MMSE (点) & $28.3 \pm 2.3^{*}$ & $29.4 \pm 0.8^{*}$ \\
TMT-A (sec) & $182.4 \pm 56.1$ & $143.0 \pm 51.8$ \\
B/F 操作管理 & 自立 4名, 非自立 3 名 & 自立 7名, 非自立 0 名
\end{tabular}

\begin{tabular}{lcc}
\hline 退院時歩行非自立群 $(9$ 名 $)$ & \\
MMSE (点) & $24.1 \pm 3.0^{*}$ & $26.3 \pm 3.3 * \dagger$ \\
TMT-A (sec) & $265.0 \pm 142.0$ & $247.0 \pm 123.5$ \\
B/F 操作管理 & 自立 1 名, 非自立 8 名 & 自立 3 名, 非自立 6 名 \\
\hline
\end{tabular}

MMSE : Mini Mental State Examination, TMT-A : Trail Making Test PartA.

* : 同時期における群間有意差, †：同群内における評価時期間有 意差.

いずれも $\mathrm{P}<0.05$ を有意差とした。

かった．そのため, この結果のみでは歩行能力獲得に際 しての宣言記憶の影響と, 非宣言記憶の影響を比較する 議論に進展はないと考えられる.

$\mathrm{B} / \mathrm{F}$ 操作は，車椅子とベッド間の移乗動作に直接的に 関係していない動作であり, 安全管理動作である。移乗 動作の行為を実施する前に, 安全性についての配慮が含 まれる場合にのみ必要となる動作である。この安全性に ついての配慮は，換言すれば，目的動作に直接関係しな い動作を意識的に行為の中に組み込める能力を持ってい るということになる．この能力の有無が, $\mathrm{B} / \mathrm{F}$ 操作管理 定着の可否を分けたということが言えるのかもしれな い. 歩行動作に関連させると, 歩行動作に直接関係しな い意識的な安全配慮（例えば, 歩行路周囲への注意等の 安全管理動作など）を行えるか否かは, 歩行の自立度に 多大な影響を及ぼすと考えられる。この能力は, 我々の 先行研究 13) で考察した記憶能力とは異なる能力であり, 脳卒中患者の動作自立度を左右する他の側面としての能 力を反映しているのかもしれない.

また車椅子 $\mathrm{B} / \mathrm{F}$ 操作管理能力の評価は, 臨床場面で 簡便に行える利点を有している。認知機能評価として一 般的に使用されている MMSEや HDS-R 等の机上検査 や認知 FIM は，いずれもまとまった評価時間や評価時 の精神的ストレスが否めず，患者への負担，また評価者 の負担も少なからず生じる。その点で, 車椅子 $\mathrm{B} / \mathrm{F}$ 操 作管理能力の評価は, 患者, 評価者の負担もほほ皆無で あり，臨床で行う評価として提案できると考える．

本研究の制限としては，(1)被験者数が少ないこと，(2) 車椅子 $\mathrm{B} / \mathrm{F}$ 操作管理能力の評価の再現性・信頼性が不 明確であることが挙げられる。これらについてさらに検 討するとともに, 注意障害の行動評価尺度である
Behavioral Assessment of Attentional Disturbance 等の他 の指標との相関関係や歩行以外の動作や行為能力との関 連についても検討を加え, 脳卒中患者の行為能力向上に 繋がる研究を進めていく.

\section{引用文献}

1) 平野恵健, 林 健, 新田 収・他: 回復期リハビリテーショ ン病棟に入院した脳卒中重度片麻痺者の退院時 ADL 能力に 及ぼす因子の検討。理学療法科学, 2015, 30: 563-567.

2) 鈴木英二, 間嶋 満, 鶴川俊洋 - 他 : 脳卒中回復期前期 における患者の層別化の試み.リハビリテーション医学, 2004, 41: 540-547.

3) 鄭 丞姫, 近藤克則: 回復期リハビリテーション病棟にお ける自立度予測。総合リハ, 2014, 42: 533-538.

4) 平野恵健, 西尾大祐, 皆川知也·他: 回復期リハビリテーショ ン病棟入院時の移乗能力が脳卒中片麻痖患者の臨床経過に 及ぼす影響. J Jpn Health Sci, 2014, 17: 95-102.

5) 園田茂: 脳卒中片麻疩患者の機能評価法 Stroke Impairment Set（SIAS）の信頼性㧍よび妥当性の検討（1）. リハビリテーション医学, 1995, 32: 123-122.

6) 西尾大祐, 平野恵健, 伊藤志保·他: 回復期リハビリテーショ ン病棟に抢ける重症脳卒中患者の転帰と臨床的特徵。脳卒 中, 2010, 32: 86-90.

7) 桂 賢一, 徳永 誠, 三宮克彦·他: 回復期リハビリテーショ ン病棟に入院した脳卒中患者の入院時・入院 1 力月後の移 動能力と退院時の移動能力との関係. 総合リハ, 2008, 36: 289-295.

8) 平野恵健, 新田 収, 高橋秀寿・他：ロジスティック回帰 分析を用いた重度脳卒中片麻瘦患者の歩行可否に及ぼす影 響一回復期リハビリテーション病棟での試み一. 理学療法 科学, 2014, 29: 885-890.

9) Stephens S, Kenny RA, Rowan E, et al.: Association between mild vascular cognitive impairment and impaired activities of daily living in older stroke survivors without dementia. J Am Geriatr Soc, 2005, 53: 103-107.

10) Ozdemir F, Birtane M, Tabatabaei R, et al.: Cognitive evaluation and functional outcome after stroke. Am J Phys Med Rehabil, 2001, 80: 410-415.

11) Paker N, Bugdayci D, Tekdös D, et al.: Impact of cognitive impairment on functional outcome in stroke. Stroke Res Treat. 2010: 652612

12) 大田尾浩, 八谷瑞紀, 村田伸 - 他：脳卒中片麻痺患者の 歩行自立に影響を及ぼす要因一認知機能が低下した患者を 対象に含めた検討一. Japanese Journal of Health Promotion and Physical Therapy, 2011, 1: 93-99.

13) 長井亮祐, 月成亮輔, 菊池俊明 - 他 : 車椅子移乗時に打け るブレーキ・フットレストの操作管理と歩行予後予測の関 係一回復期リハビリテーションの脳卒中患者を対象として一. 理学療法の科学と研究, 2015, 6: 19-21.

14) Larry RS: The neuropsychology of human memory. Annu Rev Neurosci, 1982, 5: 241-273. 